\title{
Compiling Integrated Entrepreneurship Module by Using Design-Based Research Approach to Improve Students' Entrepreneurial Skill
}

\author{
Ninik Sudarwati ${ }^{1}$ \\ ${ }^{1}$ STKIP PGRI Jombang, East Java, Indonesia \\ Correspondence: Ninik Sudarwati, STKIP PGRI Jombang, East Java, Indonesia. E-mail: ninik_009@yahoo.com
}

Received: August 9, 2017

Accepted: August 22, $2017 \quad$ Online Published: January 30, 2018

doi: $10.5539 /$ jsd.v11n $1 \mathrm{p} 83$

URL: https://doi.org/10.5539/jsd.v11n1p83

\begin{abstract}
This study aimed to develop a complete practical comprehensive module to improve students' entrepreneurial skills, particularly to their managerial aspects. Research and development approach with design based research (Elly and Levy, 2010) was employed as the technique of this present study. For data collection and analysis throughdesign-based approach, several procedures were conducted, which involved problem identification, objectives framing, product design and development, product examination and test, result evaluation, and result communicating. The result of this research showed that the integrated entrepreneurship module was ultimately able to improve the students' capability $(80 \%)$ in both explaining and applying the concept of managerial aspects and entrepreneurial skills. As the result, this research finally produced an integrated module containing 3 chapters and 12 topics. Chapter 1 described on how to initiate entrepreneurial passion and consisted of 5 complete topics. Chapter 2 described on how to manage and run a business and it contained 6 topics. Chapter 3 described on how to implement a business plan and it consisted of 1 topic only. With this module, $80 \%$ students were found successful understanding the given materials and implementing the management aspects in their entrepreneurial practice. Thus, the null hypothesis proposing that students' entrepreneurial skills would be significantly improved was considered supported.
\end{abstract}

Keywords:entrepreneurship, module, trial

\section{Introduction}

An integrated module used as the main source of the entrepreneurship course commonly consists of some different topics and materials such as entrepreneurial mental reinforcement, how to manage a business, a practical guidance in term of initiating a business and implicating managerial aspects. It has some definite characteristics; simple and practical, applicative, and complete since it integrated with several case studies, worksheets, and Q\&A keys in order to measure the level of mastery of the given material. Textbooks are used as means to describe the process of information in which students' knowledge and purposes influenced within (Kozma, 1991). Creativity can be well learned with a good communication among students and teachers realizing the importance of each role to create an effective learning atmosphere (Sousa, 2010). Similarly, some believe that creativity may influence many aspects in education; giving a great impact in real life, encouraging students to be a more powerful and competitive next generation, creating a future orientation, reaching the reforms in politics, economy and cultural fields (Shaheen, 2010). Hence, an integrated entrepreneurial module plays a significant role in a learning process as the vital media to encourage students' entrepreneurship skill.

A course of entrepreneurship is useful for learners to improve certain areas of their working skills; creating business opportunities, increasing financial revenue, developing the boldness and independency in entrepreneurship (Jehanzeb, 2013). In addition, Alkali (2012) stated that highly educated entrepreneurs achieved better performance in running the business. As the result, he recommended to involve trained and educated entrepreneurs and in order to improve students' entrepreneurial skills and training competence, and in turn, it would carry out an effective entrepreneurial impact for them. The governments raising revenue should focus on increasing human resources and technology, as well as the promotion of enterprise development (Acs, et al, 2006).

Furthermore, an interview talking about an expected integrated module for entrepreneurship course resulted in an 
expectation to have a module with: 1) practical and simple materials on entrepreneurship, 2) explanation on how to manage the business and encouraging the entrepreneurship mental, and 3) a comprehensive composition and content. It deals with management aspects, entrepreneurial ethics, module design, and business plan compiled within. In addition, realizing the importance of business plan (Richbell, 2006), an effective entrepreneurship module is necessary to develop with 2 major principles involving business skills and entrepreneurial traits (Kee et al., 2007).

This present study would construct an integrated module of entrepreneurship by using design-based approach. It would also evaluate the effectiveness of the module as well, particularly to students' improvement of management aspect of entrepreneurship. Two hypotheses were proposed as follow.

\section{$H_{0}$ : No improvements were found in students' entrepreneurial practice after the module was applied.}

$H_{a}$ : Improvements were found in students' entrepreneurial practice after the module was applied.

\section{Method}

Applying research and development method using design-based approach, eventually, this research is conducted through iterative analysis based on the synergic collaboration between practitioner and researcher. Conducting the research by applying the principal phase of design based research, this present research adopted the 6 phase model by Peffer (Elly\&Levy, 2010: 111), as follows:

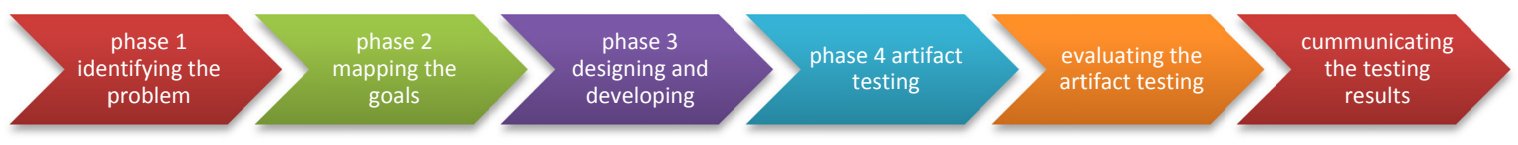

Figure 1.The research procedures

For validity, a cross validation technique for all stages was applied. A discussion on rucial issues dealing with the research objectives was conducted among students, instructor and the course committee as well. This study was conducted between August and November 2012. The module was trialed on January 2015 at Bangun Pertiwi Course, Andini Course, and Nirmala Course -public private tailor courses in Jombang, East Java. This trial would provide revision for module. 40 students from different entrepreneurial courses $(20$ students were from fashion course, 10 were from shoe tailoring course, and 10 were from makeup course) participated in this study. To measure the effectiveness of this module, several procedures were conducted, such as: (1) analyzing the module through t-test, (2) pre-testing it to the participants, by providing them 5 short essay questions for measuring their' managerial skill on entrepreneurship, and (3) having a post-test with 5 questions in order to assess and evaluate students' achievement in term of their managerial skills on entrepreneurship, Standard Likert4-point through which 4 for answer A, 3 for answer B, 2 for answer C, and 1 for answer D, was also applied for both pre-test and post-test; (4) measuring the standard deviation through t-test, as follow.

$$
t_{0}=\frac{M_{1}-M_{2}}{S E_{M_{1}-M_{2}}}
$$

Description:

$\mathrm{SE}_{\mathrm{M} 1-\mathrm{M} 2}=$ Standard error (mean deviation between sample I and sample II)

$\mathrm{M}_{1}-\mathrm{M}_{2}=$ variable diversity before the test $\left(\mathrm{X}_{1}\right)$ with mean variable after the test $\left(\mathrm{X}_{2}\right)$

(Montgomery, 2001)

And (5) varifying the validity of the module by having an interview dealing the design and contents.

\section{Result}

\subsection{Identifying the Problems}

According to the observation conducted, it found that $80 \%$ of the students participating on each of those courses mostly came from high school, while $10 \%$ of them had graduated from junior high school, and the remaining $10 \%$ of them were non-graduated students. In general, students with high school degree have more capacity to receive the materials and, in turn, enhance their confidence. The data of pre-test was useful to provide a general knowledge of entrepreneurial skills, including: business ethic, working ethic, collaboration, customers trust building, cash flow, and advertising. In line with the expectation toward the integrated entrepreneurial module, it made students more competitive, creative, innovative, and able to manage a business, organize the cash flow and 
effectively control the business cost. Overall, several outlooks in compiling an integrated entrepreneurial module were successfully identified.

\subsection{Formulating the objective, Design and Limitation of the Content}

It assumed that framing the objectives and scope on two major principles of module design and content was necessary to make an integrated module effective before it was verified onto the related courses.

\subsection{Designing the Module}

In order to produce a practical module, it needed to consider some crucial notions such as: 1) students' educational background, and 2). more practical rather than theoretical tips dealing with entrepreneurial traits and managerial aspect.

\subsection{Content of the Module}

On the basis of identifying the problem, verification on the data collected resulted in: 1) the composition of materials covers the spirit in running a business, fostering creativity, business cooperation, and managing the business, 2) practical and applicable theories attributed with examples and tasks, 3) autonomous learning-based design. Those all pointed to both students' and instructors' expectations, which wanted to discover an appropriate set of effective evaluation (Henry, 2004).

\subsection{Designing, Drafting, and Developing the Module}

Designing this integrated module involved three major parties; the students, the course manager, and the tutors. The draft of the module was classified into three sections as follow.

1) The Initial. It described the correlation between each chapter along with its characteristics, provided the prerequisite of using the module, and verified 4 major objectives for business development. Also, it provided a brief explanation and evaluation to do the given exercises.

2) The Main. It consisted of three chapters respectively talking about entrepreneurship skill, business skill, and how to make an integrated business plan. Specifically, each chapter was different in: a) title -(1) Chapter 1: initiating entrepreneurship traits, (2) Chapter 2: managing the business, and (3) Chapter 3: business planning; b) Goals and objectives comprehensively described within each chapter; and c) topics -(1) Chapter 1 consisted of 5 topicsincluding the concept of entrepreneurship, entrepreneur as the leader, decision making and risk taking, creativity, and negotiating skill; (2) Chapter 2 consisted of 6 topics including determining and planning to produce a new product and market it to the customers, marketing and sales planning, counting break event points, financial and cash flow statements, human resource developments, and annual business planning; and Chapter 3 consisted of 1 topic discussing about how to draft a business plan.

3) The Final. It provided 1) closing statements containing general guidance on what students should do next using integrated entrepreneurial module, and 2) bibliography, providing theoretical references and sources of the module.

\subsection{Validation through T-test}

Based on the data collection through questionnaire, the result of statistical measurement with T-test (table) of two sample using SPSS 20 windows with paired sample T test method came up as follows.

Table 1. Paired samples statistics

\begin{tabular}{lllrrr}
\hline & & Mean & N & Std. Deviation & Std. Error Mean \\
\hline \multirow{2}{*}{ Pair 1 } & Pretest & 18.9000 & 40 & 2.26229 & .35770 \\
& Posttest & 23.9750 & 40 & .69752 & .11029 \\
\hline
\end{tabular}


Table 2. Paired samples test

\begin{tabular}{|c|c|c|c|c|c|c|c|c|c|c|}
\hline & & & \multicolumn{5}{|c|}{ Paired Differences } & \multirow[t]{4}{*}{$\mathrm{T}$} & \multirow[t]{4}{*}{ Df } & \multirow{4}{*}{$\begin{array}{c}\text { Sig. } \\
\text { (2-tailed) }\end{array}$} \\
\hline & & & \multirow[t]{3}{*}{ Mean } & \multirow{3}{*}{$\begin{array}{c}\text { Std. } \\
\text { Deviation }\end{array}$} & \multirow{3}{*}{$\begin{array}{l}\text { Std. Error } \\
\text { Mean }\end{array}$} & \multirow{2}{*}{\multicolumn{2}{|c|}{$\begin{array}{c}95 \% \text { Confidence Interval } \\
\text { of the Difference }\end{array}$}} & & & \\
\hline & & & & & & & & & & \\
\hline & & & & & & Lower & Upper & & & \\
\hline Pair 1 & $\begin{array}{l}\text { pretest } \\
\text { postest }\end{array}$ & - & -5.07500 & 2.16484 & .34229 & -5.76735 & -4.38265 & -14.827 & 39 & .000 \\
\hline
\end{tabular}

The result showed that the third output referred to the table of paired sample test. The mean difference of pre-test and post-test was $-5.075(18.9000-23.9750)$, with standard deviation at 2.16484 and the t-value at -14.827 . The probability value or Sig value pointed to (2-tailed) $0.000<0.05$. Thus, it found that $\mathrm{H}_{0}$ was objected while $\mathrm{H}_{\mathrm{a}}$ was considered supported. In short, students' capability to apply managerial aspects into entrepreneurial practice was found improved using integrated entrepreneurial module.

According to data tabulation from questionnaires, however, it showed that $80 \%$ of the students claimed that they understood the theories of managerial aspects along with its implementation. The analysis captured their expression and behavior as well and found that (1) they were highly motivated joining the course and inspired to run their own business for some reasons, 2) they were interested in learning autonomously using the integrated entrepreneurial module, 3) they felt comfort in the process of training and found that their suggestion and expectation would be beneficial for the module.

\subsection{Evaluating the Content of the Integrated Entrepreneurship Module}

It found that $80 \%$ of the students were able to understand the materials contained in the integrated entrepreneurial module. It indicated that the module was effective as a learning media. Hence, it was considered appropriate and effective to use.

\section{Discussion}

The research and development with Design-Based Research approach resulted in 1) The implementation of each phase required sufficient time for validation, 2). The researcher of this study acted as an informative assembler and facilitator drafting the module that corresponded to the user needs, being proactive and communicative with the users, 3). A sense of belonging and good cooperation between the researcher and the users were found exist in the process of product research and development to obtain effective materials. The design-based research approach was applied in several stages which brought different result as well.

Identifying problems resulted in students' educational and economic background, and parents' job. In regard to content drafting, it was necessary to consider several aspects including 1) who the students are, (2) how their attitudes and entrepreneurial traits are, 3) the level of readiness, 4) students' motivation and innate. Those aspects eventually could contribute to an effective and interesting learning. The courses participants are mostly fresh graduate of senior high school $(80 \%)$. they were capable to receive and absorb knowledge more quickly rather than other participants from different educational background as they were more confident and actively engaged in training. The curriculum applied by the courses related to entrepreneurship is naturally practical. These entrepreneurial materials include work ethic, business initiation and material procurements, and business management and communication. The strategy of entrepreneurship learning referred to be integrative between theory and practice and simultaneously conveyed during the course (Omar, et al; 2010). The success of entrepreneurship did not always deal with the financial (capital) factor but also from non-financial factor, prominently, high personal entrepreneurial traits such as skills, innovations, dexterity to run a business as well as its problems (Malaya, 2006; Ahn, et al, 2008; Randolph, 2013). However, some courses applied a learning system separating theory from practice, and thus, would create a gap on what students really needed. In regard to this needs, it argued that a simple and practical entrepreneurial module is urgently needed. The module should cover some basic characteristics corresponding to the students' expectation, be practical and easy to learn, present in simple sentences, provide less yet comprehensive theories along with various exercises, and contain means for entrepreneurial mental building and practical business management.

In framing the objectives, it needed to scope the content which corresponded to the outcome of problem identification. Thus, the objectives should include the design and content of the modules. The design displayed an interesting layout, and the materials are presented in brief context attributed with some figures in order to 
encourage students' curiosity. In addition, the content contained work ethic, creativity for business development, business initiating, business management, and marketing development (Crea, 2010). Entrepreneurship materials contained entrepreneurship traits and business management. In module drafting, it was set in three chapters that consisted of building entrepreneurship passion, managing the business, developing practice and integrating business plan.

In module trial, it showed a significant improvement of students' skills in management aspects and entrepreneurial practice as they used the module. The validation found that it successfully met the requirement of an autonomous learning module. This is consistent with Ismail (2010) that the responses of female students are more positive than male students' toward the entrepreneurship module considering the time flexibility, working hour and managing house chores. Thus, learning with module is a kind of self-instruction individual learning model.

Finally, evaluating the effectiveness of module was measured by some quantitative measurements. The results of each trial showed that the module is found effective to be applied as an autonomous learning module. It found that $80 \%$ of the students were able to implement all the managerial aspects in business. In addition, its design mainly consisted of the initial section including title, table of contents, information maps, general purpose and evaluation guide. The main section included the topic title, learning objectives, activities, materials, evaluation, and the final section provided the module with key answers and assessment criteria.

\section{Conclusion}

Some findings were resulted from product research and development. Developing an entrepreneurship module for courses had classified into 1) Revising modules based on students and courses manager's needs and expectations, 2) The content of the module should reflect the students' needs to build their personal entrepreneurial traits. 3) Validation and revision for module was through some sets of validation test; discussion among students, instructors, and collaborator; despite a quantitative measurement to verify its effectiveness. Besides its benefits toward the students, this module is also beneficial as 1) an effective media to provide a personal guide for student personally; 2) means for effective remedial as it corresponded to student learning outcomes; 3). Applicable media for anyone and anytime, played as the facilitator assistance; 4) means to make the professional task better, making students more active through self-learning; 5) an effective reflection of learning. It showed that the use of this integrated module was significant to improve students' ability with cognitive strategy. It was capable to make the learning process more active and sustainable. (Akpomi, 2009).

However, this module had some limitations, such as 1) it was less instruction, making this suitable for classroom-based learning or outdoor-group activity, noted that the assumption of students' ability to learn and complete individual tasks entirely could not be entrusted; 2) a single approach made the activity monotonous and boring, and thus, making students more introvert and resulted in lower achievements; 3) Irresponsible independency, making students not interested to do the tasks (these trait belonged to some students already); 4) learning process still needed some supporting facilities like media and adequate learning resources; 5) the module was not equipped with media such as audio or video which might help students to be more active acquiring relevant sources; and 6) It was relatively more expensive than the lecturing method.

After having data collection and module revision, it suggested that this module had some sections. At the first section, it was entitled "Integrated Entrepreneurship Module for Entrepreneurial Candidates", consisting of title, preface, table of contents and introduction that described background, module user prerequisites, general purpose of the module, module usage and ability evaluation as well. At the second section, it consisted of three chapters including Chapter I "Entrepreneurship skills", Chapter 2 "Business skills", and Chapter 3 "Practice Preparing an Integrated Business Plan". Chapter 1 contained five topics including the concept of entrepreneurial characteristics, an entrepreneur as a leader, making decision and taking risk, creativity, and negotiation skills. Chapter 2 contained six topics which included defining new products to production planning, marketing and sales plans, break even points, financial reporting, human resource management and business planning. Chapter 3 contained one topic referring to the practice of developing a business plan (Faria, 2009). The design structure of each topic described the learning objectives, learning activities, materials, topic summary, answer keys, assessment criteria and bibliography. The final section contained a concluding remark

Additionally, this module was earmarked for: 1) course managers who highly recommended to periodically review the material with the applied entrepreneurship curriculum in accordance to the science and business technology; 2) course instructors for mastering the content of materials in order to guide the learners individually (Likoko : 2013); and 3) students for learning the theory and practicing their entrepreneurship skill. Any further researches are necessary to develop entrepreneurship training module with electronic media using audio-visual 
display for people living in digital era like nowadays. Overall, since entrepreneurship courses provide informal education and are aimed for adult learners, the use of such module is vital for their autonomously flexible learning.

\section{References}

Acs, Z. I., \& Szerb, L. (2007). Entrepreneurship, Economic Growth and Public Policy. Small Business Economic, 28, 109-122. https://doi.org/10.1007/s11187-006-9012-3

Ahn, M., J., \& Meeks, M. (2008). Building a Conducive Environment for Life Science-based Entrepreneurship and Industry Clusters. Journal of Commercial Biotechnology, 14(1), 20-30. https://doi.org/10.1057/palgrave.jcb.3050076

Akpomi, M. E. (2009). Entrepreneurship Education (EE) For All Student in Higher Education Institution (HEIs) in Negeria: A Means to Sustainable Development. Journal of Sustainable Development in Africa, 11(1), 163-173.

Alkali, M. (2012). An Empirical Study Entrepreneurs Educational Level an The Performance of Small Business Manufacture Enterprises in Bauchi State, Nigeria. Interdiciplinery Journal of Contemprary Research Business (IJCRB), 4(6).

Crea, E., \& Mc., A. (2010). Integrating Service-Learning Into an Introduction to Entrepreneurship Course. Journal of Management Education, 34(1), 39-61. https://doi.org/10.1177/1052562909337906

Elly, J., \& Levy, Y. (2010). A Guide for Novice Researchers: Design and Development Research Methods. Proceedings of informing, Science \& IT Education Conference (Insite) 2010, Pp. 107-118.

Faria, A. J., Hutchinson, D., \& Wellington, W. J. (2009). Developments in Business Gaming. Simulation \& Gaming, 40(4), 464-487. https://doi.org/10.1177/1046878108327585

Henry, C. (2004). The Efectiveness of Training for New Business Creation. International Small Business Journal, 22(3), 249-271. https://doi.org/10.1177/0266242604042378

Ismail. (2010). Acceptance of entrepreurship Culture Module at The Malaysian Institute of Higher Learning: Agender Perpesctive. Research Journal of International Studies, (15), 46-54.

Jehanzeb. (2013). Training and Development Program and its Benefits to Employee and Organization: A Conceptual Study. European Journal of Business and Management, 5(2), 243-252.

Kee, J., Rodriques, P., Kundu, S., \& Racine, J. L. (2007). Entrepreneurship Curiculum. Project Report For JIP Grant. Retrieved from www.sylff.org/pdf/fellows/JIP2006_23.pdf

Kozma, R. B. (1991). Learning with Media. Review of Educational Research, 61(2), 179-212. https://doi.org/10.3102/00346543061002179

Likoko, S., Mutsotso, S., \& Masongo, J. (2013). Tutor Competence and its Effect on Quality of Teacher Preparation in Emerging Private Primary Teacher Training Colleges in Bungoma County- Kenya. Journal of Education and Practice, 4(2), 95-102.

Malaya, M. F. (2006). A Gender-Based Analysis of Performance of Small And Medium Printing Firms In Metro Manila. Journal of International, 8(1), 83-95.

Montgomery, D. C. (2001). Design And Analysis Of Experiments (5th ed.). Jhon Wiley \& Sons, Inc., New York, the United States of America.

Omar, A. F., Ishak, S., \& Rahid, M. R. (2010). Consultation-Based Entrepreneurial/Business Learning: Malaysia Experience. African Journal of Business Manajemen, 4(12), 2508-2513.

Randolph. (2013). Developing Global Business Capabilities in MBA Student. Journal of Management Inquiry, 20(3), 223-240. https://doi.org/10.1177/1056492611401027

Richbell, S. M., Watts, H. D., \& Wardle, P. (2006). Owner-Managers and Business Planning in the Small Firm. International Small Business Journal, 24(5), 496-514. https://doi.org/10.1177/0266242606067275

Shaheen, R. (2010). Creativity and Education. Creative Education, 1(3), 166-169. https://doi.org/10.4236/ce.2010.13026

Sousa, F. C. (2010). Creative Teaching and Effective Teaching in Higher Education, "2010 Outstanding Paper" The International Conference of Organisational Innovation, Bangkok, Thailand, August, 2010. 


\section{Copyrights}

Copyright for this articleis retained by the author(s), with first publication rights granted to the journal.

This is an open-access article distributed under the terms and conditions of the CreativeCommons Attribution license (http://creativecommons.org/licenses/by/4.0/). 